\title{
Low Tunnels inside Mediterranean Greenhouses: Effects on Air/Soil Temperature and Humidity
}

\author{
Alejandro López-Martínez ${ }^{1, *(\mathbb{D})}$, Francisco D. Molina-Aiz ${ }^{1}\left(\mathbb{D}\right.$, María de los Ángeles Moreno-Teruel ${ }^{1}(\mathbb{D}$, \\ Araceli Peña-Fernández ${ }^{1}\left(\mathbb{D}\right.$, Fátima J. F. Baptista ${ }^{2}\left(\mathbb{D}\right.$ and Diego L. Valera-Martínez ${ }^{1}$ (D) \\ 1 Research Centre CIAIMBITAL, University of Almería, Ctra, de Sacramento s/n, 04120 Almería, Spain; \\ fmolina@ual.es (F.D.M.-A.); mamorenoteruel@ual.es (M.d.l.Á.M.-T.); apfernan@ual.es (A.P.-F.); \\ dvalera@ual.es (D.L.V.-M.) \\ 2 MED—Instituto Mediterrâneo Para a Agricultura, Ambiente e Desenvolvimento, \\ Departamento de Engenharia Rural, Escola de Ciências e Tecnologia, Universidade de Évora, \\ 7000-849 Évora, Portugal; fb@uevora.pt \\ * Correspondence: alexlopez@ual.es
}

Citation: López-Martínez, A.; Molina-Aiz, F.D.;

Moreno-Teruel, M.d.l.Á.;

Peña-Fernández, A.; Baptista, F.J.F.;

Valera-Martínez, D.L. Low Tunnels

inside Mediterranean Greenhouses:

Effects on Air/Soil Temperature and Humidity. Agronomy 2021, 11, 1973.

https://doi.org/10.3390/

agronomy11101973

Academic Editor:

Alberto San Bautista

Received: 28 August 2021

Accepted: 27 September 2021

Published: 30 September 2021

Publisher's Note: MDPI stays neutral with regard to jurisdictional claims in published maps and institutional affiliations.

Copyright: (c) 2021 by the authors. Licensee MDPI, Basel, Switzerland. This article is an open access article distributed under the terms and conditions of the Creative Commons Attribution (CC BY) license (https:/ / creativecommons.org/licenses/by/ $4.0 /)$.

\begin{abstract}
The main objective of this work was to analyze the microclimate generated inside a low tunnel (floating row cover) installed in an Almería-type greenhouse. Low tunnels are commonly used in the open field to protect plants against insect attack and to improve the production of muskmelon and strawberry. Floating row covers can also be used inside greenhouses during the first few weeks after the transplantation of muskmelon and watermelon crops in spring-summer cycles. This work was carried out during the first weeks of a watermelon culture (Citrullus lanatus Thunb.) growing with a polyethylene row cover inside an Almería-type greenhouse $\left(2115 \mathrm{~m}^{2}\right)$. Air temperature and humidity, plant temperature and soil temperature and humidity were measured in the greenhouse inside and outside the row covers. During the three days of measurement, all greenhouse vent openings were closed. The use of the low tunnels increased average air temperature around plants from $24.0 \pm 9.0^{\circ} \mathrm{C}$ to $26.9 \pm 9.7^{\circ} \mathrm{C}$. A maximum difference in air temperature of about $5.9^{\circ} \mathrm{C}$ was observed at noon. The average daily temperature of the crop was $28.2 \pm 11.8^{\circ} \mathrm{C}$ inside the row cover and $24.6 \pm 8.9^{\circ} \mathrm{C}$ without it. Similarly, the absolute humidity of air was clearly higher inside the low tunnel $(0.0201 \pm 0.0098 \mathrm{~g} / \mathrm{g})$ than around the plant rows without floating cover $(0.0131 \pm 0.0048 \mathrm{~g} / \mathrm{g})$. The soil temperature was also higher inside the low tunnel compared to the area without this second plastic cover. The effect of the tunnel decreased with depth, with average temperature differences of $1.2 \pm 0.5^{\circ} \mathrm{C}$ on the soil surface and $0.6 \pm 0.5^{\circ} \mathrm{C}$ at $20 \mathrm{~cm}$ depth.
\end{abstract}

Keywords: floating row cover; crop protection; watermelon; air temperature; soil

\section{Introduction}

Low tunnels (floating row cover) are small arched metal structures, covered with plastic film that provides protection to crops in their early stages of development [1-4]. For example, high or low tunnels are usually used for strawberry cultivation [5]. For the low tunnels, colorless translucent plastic film is often used, similar to that used on the cover of Mediterranean greenhouses [6], usually of polyethylene [7,8]. The main objective of these low tunnels is the advancement or delay of the growing cycle [9,10], thus allowing production to be obtained at times of the year where without this technique it would not be possible. The use of low tunnels produces an increase in the temperature of the air and soil [11,12], which favors the growth of crops [11,13,14]. Other authors have measured higher air relative humidity under low tunnels than without low tunnels $[15,16]$. In addition, the low tunnels protect against frost $[17,18]$. They are usually used in outdoor crops [1], although they can also be used in crops inside greenhouses to give extra protection in the early stages of cultivation. Plastic greenhouses are productive structures that have become widespread in regions with mild winters and in regions with warm climates [19], 
as, for example, in southeastern Spain [20]. The use of low tunnels is rare inside the Mediterranean greenhouses. For example, only $6 \%$ of the greenhouses of the province of Almería (Spain) used low tunnel to protect horticultural crops at the early stages of growth [7]. When growing the crop, the leaves touch the plastic, and it is necessary to remove the low tunnel. These low tunnels allow increasing the air temperature surrounding the seedlings by decreasing energy losses by infrared radiation at night. Placing them above heating pipes allows great energy savings by greatly limiting heat losses by convection to the rest of the greenhouse [7].

The dimensions and types of materials used for the low tunnel, as well as the date of placement and removal, will depend on the requirements of each type of crop [9]. For example, for crops such as strawberry, a minimum height of $40-60 \mathrm{~cm}$ is sufficient. Low tunnels (30-40 cm high and 40-50 cm wide) are commonly used in watermelon and melon crops in open fields [9]. However, for crops such as tomato or pepper is necessary to increase the height. The appropriate height also depends on the time to use the low tunnel and the climatic conditions of the area [9]. Low tunnels can also be used with perforations or openings in the plastic film [21]. As for handling, they can be opened and closed at certain times of the day [21]. These low tunnels usually are removed progressively, increasing the degree of opening until their total removal [1].

These low tunnels with polyethylene film were analyzed by Loy and Wells [22] in a hybrid muskmelons crop in an open field. Air temperatures reached inside the low tunnels during the daytime were $4-5{ }^{\circ} \mathrm{C}$ higher than the air temperature outside the tunnels, advancing the ripening of the fruit between 12 and 13 days.

Gerber et al. [6] found that the use of these structures, inside a glass greenhouse, favored the growth of a pepper crop, as well as its yield and fruit quality, according to observations by Jolliffe and Gaye [23]. Abak et al. [24] also observed an increase in production using low tunnels in a Physalis crop grown in an open field, with respect to unprotected plants.

Other authors have observed that, in open-air muskmelon crops, higher production was obtained by combining plastic mulch and low tunnels, compared to the use only of plastic mulch or only low tunnels [25]. The bibliographic references found refer mainly to the use of these protection structures in outdoor crops. The main objective of this work is to analyze the modifications in the microclimate generated inside a low tunnel, installed inside an Almería-type greenhouse, during the first weeks after transplanting a watermelon crop in a summer spring cycle.

\section{Materials and Methods}

\subsection{Experimental Greenhouse}

The test was carried out in an Almería-type greenhouse with a structure type "Raspa y Amagado" [7] with an area of $2115 \mathrm{~m}^{2}(45 \times 47 \mathrm{~m})$ located at the "Catedrático Eduardo Fernández" experimentally farm of the UAL-ANECOOP Foundation $\left(36^{\circ} 51^{\prime} \mathrm{N}, 2^{\circ} 16^{\prime} \mathrm{W}\right.$; $87 \mathrm{~m}$ elevation), in the province of Almería, Spain. The greenhouse is equipped with side vents throughout its perimeter and three roof vents. The ventilation surface was $16.2 \%$ of the greenhouse soil surface; although during the test, the vents remained closed.

A watermelon crop (Citrullus lanatus Thunb.) was transplanted inside the experimental greenhouse. The material selected was 285 Fenway triploid watermelon plants grafted onto RS841 (T) and 140 Premium diploid watermelon plants grafted onto RS841 (D), with a plant density of 0.25 plants $/ \mathrm{m}^{2}$. The low tunnels were used to modify the microclimate around the seedlings during the first development stage. These low tunnels provide watermelon seedlings with an additional thermal coat inside the greenhouse, allowing the advance of the transplant date of the crop in spring-summer cycles. Each low tunnel, $75 \mathrm{~cm}$ wide and $50 \mathrm{~cm}$ high, protects a complete crop line (Figure 1). A steel round structure $(1 \mathrm{~cm}$ diameter) and a non-perforated low-density polyethylene (LDPE) plastic film protective material were used for the low tunnel. 


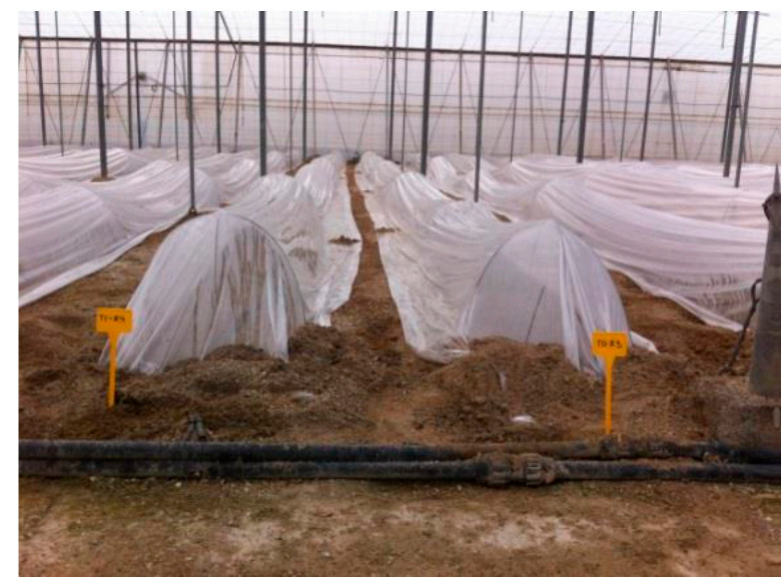

(a)

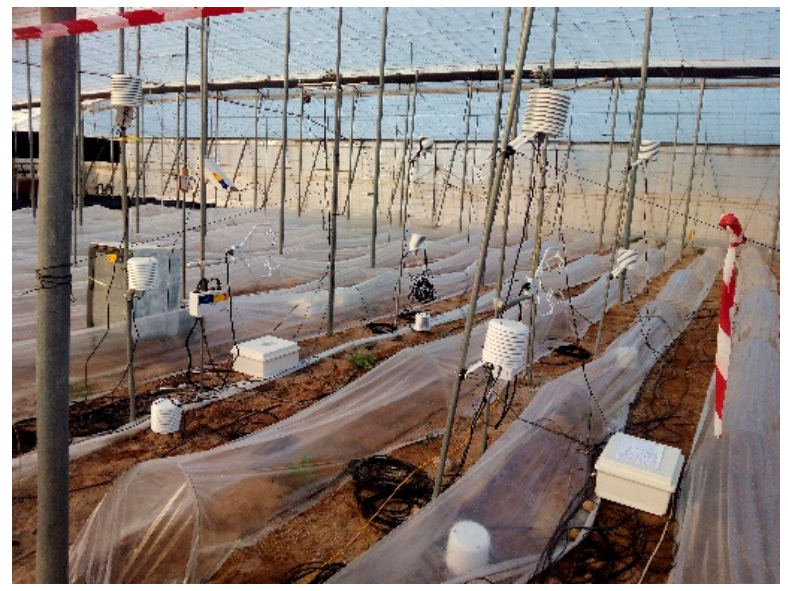

(b)

Figure 1. Low tunnels installed inside the experimental greenhouse (a) and measurement equipment (b).

\subsection{Equipment and Instrumentation}

In order to study the effect of low tunnels on the microclimate surrounding the plant, two zones were established for the measurement of different microclimatic parameters. A crop line remained unprotected (without the low tunnel) during the test and all other crop lines were kept protected under low tunnels (Figures 1 and 2). The measures were carried out in the central part of the greenhouse and in areas near the aisle of the greenhouse (Figure 2). Air temperature and humidity were measured with 12 CS215 sensors (Campbell Scientific Spain S.L., Barcelona, Spain) with an SHT75 (Sensirion AG, Zurich, Switzerland) multi sensor module based in complementary metal-oxide-semiconductor CMOSens ${ }^{\circledR}$. The device includes a capacitive polymer sensing element for relative humidity and a silicon band-gap temperature sensor (accuracy for air temperature of $\pm 0.4{ }^{\circ} \mathrm{C}$ over 5 to $40{ }^{\circ} \mathrm{C}$ and $\pm 0.9{ }^{\circ} \mathrm{C}$ over -40 to $70{ }^{\circ} \mathrm{C}$; accuracy for relative humidity of $\pm 2 \%$ over 10 to $90 \%$ $\mathrm{RH}$ and $\pm 4 \%$ over 0 to $100 \%$ at $25^{\circ} \mathrm{C}$ ). The sensors were protected from radiation inside a naturally aspirated box 41003-5 (Campbell Scientific Spain S.L.). The temperature and humidity of the air were measured in three different heights: next to the crop at $0.2 \mathrm{~m}$, and above the crop and low tunnels at $1 \mathrm{~m}$ and $2 \mathrm{~m}$ in height (Figures 1 and 2). The temperature of the crop was measured using two Thermistor 108 (Campbell Scientific Spain S.L.; accuracy of $\pm 0.1^{\circ} \mathrm{C}$ over 0 to $70{ }^{\circ} \mathrm{C}$ ) attached to the crop leaves. Solar radiation was measured inside the greenhouse ( $2 \mathrm{~m}$ high) with two SP1110 Pyranometers (Campbell Scientific Spain S.L.; sensitivity range of 350-1100 nm; accuracy of $\pm 5 \%$ ). Two SKP215 Quantum sensors (Skye Instruments Ltd., Llandrindod Wells, UK; measurement range of 0 to $5 \times 10^{4} \mu \mathrm{mol} \mathrm{m}{ }^{-2} \mathrm{~s}^{-1}$; accuracy of $\pm 5 \%$ ) were used to measure photosynthetically active radiation (PAR). Net radiation was measured using two NR-Lite2 Radiometers (Kipp \& Zonen B.V., Delft, The Netherlands; spectral response: 0 to $100 \mu \mathrm{m}$; measurement range of $\pm 2000 \mathrm{~W} \mathrm{~m}^{-2}$; accuracy of $\pm 5 \%$ ). The air velocity was measured (at $1 \mathrm{~m}$ height) using two 3D sonic anemometers (model CSAT3, Campbell Scientific Spain S.L.; resolution $0.001 \mathrm{~m} \mathrm{~s}^{-1}$ for $u_{x}, u_{y}$ and $0.0005 \mathrm{~m} \mathrm{~s}^{-1}$ for $u_{z}$; and accuracy $\pm 0.04 \mathrm{~m} \mathrm{~s}^{-1}$ for $u_{x}, u_{y}$ and $\pm 0.02 \mathrm{~m} \mathrm{~s}^{-1}$ for $u_{z}$ ). The temperature on the ground surface was measured using two TCAV type E thermocouples (Campbell Scientific Spain S.L.; measurement range of - 200 to $0{ }^{\circ} \mathrm{C}$ and 0 to $900{ }^{\circ} \mathrm{C}$; accuracy of $\pm 1.7 \%$ ), these sensors were buried superficially [26]. The temperature inside the ground $(5,10,15$, and $20 \mathrm{~cm}$ deep) was measured using eight Thermistor 108 (Campbell Scientific Spain S.L.) (Figure 2) [26]. The moisture content in the soil (20 cm deep) was measured with two CS616 Water Content Reflectometers (Campbell Scientific Spain S.L.; measurement range of 0 to $50 \%$ VWC (volumetric water content); accuracy of $\pm 2.5 \%$ ), placed horizontally (Figure 2 ). The data from these sensors were stored in five CR3000 Microloggers (Campbell Scientific Spain S.L.) with a frequency of $1 \mathrm{~Hz}$ [27]. 


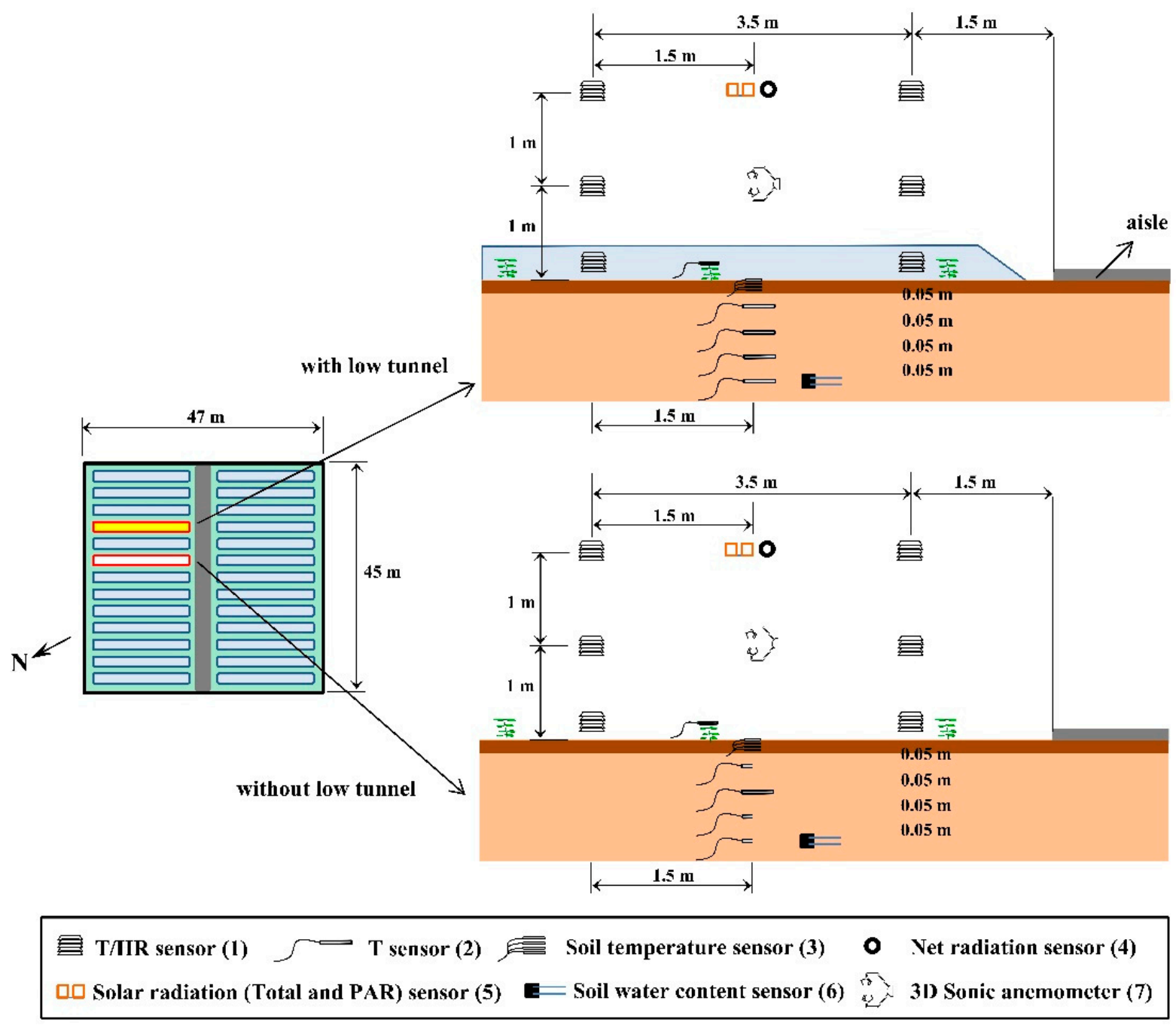

Figure 2. Experimental setup and location of sensors used in the test.

Outside climatic conditions were measured $75 \mathrm{~m}$ away from the northern side of the experimental greenhouse (at $10 \mathrm{~m}$ of height). Outside air temperature and humidity were measured with a CS215 sensor, outside Solar and PAR radiation were measured with an SP1110 Pyranometer and an SKP215 Quantum sensors, respectively. The data from these sensors were stored in another CR3000 Micrologger (Campbell Scientific Spain S.L.) with a frequency of $1 \mathrm{~Hz}$. Outside wind speed was measured with a Meteostation II (Hortimax S.L., Almería, Spain), incorporating a cup anemometer (measurement range of 0 to $40 \mathrm{~m} \mathrm{~s}^{-1}$; accuracy of $\pm 5 \%$ ) and a vane for wind direction (accuracy $\pm 5^{\circ}$ ). The Meteostation II measurements were stored in an independent computer system every minute [28].

Climatic parameters were measured from 3 to 5 March 2015 (Table 1). The duration of the test was limited to three days, to avoid damage in the plants that were unprotected outside the low tunnel.

\subsection{Statistical Analysis}

Multiple range tests were carried out using the software Statgraphics Plus (Manugistics Inc., Rockville, MD, USA). Fisher's least significant difference (LSD) was used to determine the statistical differences between climatic parameters, establishing the confidence level at $99 \%$. 
Table 1. Outside climatic conditions (average value \pm standard deviation): $u_{0}$, wind speed ( $\mathrm{m} \mathrm{s}^{-1}$ ); $\theta$, wind direction $\left({ }^{\circ}\right) ; H R_{o}$, air relative humidity (\%); $T_{o}$, air temperature $\left({ }^{\circ} \mathrm{C}\right) ; R_{o}$, solar radiation

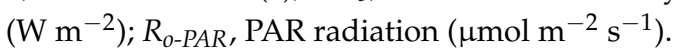

\begin{tabular}{ccccccc}
\hline Date & $\boldsymbol{u}_{\boldsymbol{o}}$ & $\boldsymbol{\theta}^{\mathbf{a}}$ & $\boldsymbol{T}_{\boldsymbol{o}}$ & $\boldsymbol{H R}_{\boldsymbol{o}}$ & $\boldsymbol{R}_{\boldsymbol{o}}$ & $\boldsymbol{R}_{\boldsymbol{o}-\boldsymbol{P A R}}$ \\
\hline \multicolumn{7}{c}{ Daily } \\
\hline 3 March 2015 & $0.7 \pm 0.6$ & $176 \pm 112$ & $13.7 \pm 3.0$ & $93 \pm 11$ & $179 \pm 280$ & $377 \pm 590$ \\
4 March 2015 & $1.8 \pm 2.2$ & $150 \pm 102$ & $13.7 \pm 2.1$ & $92 \pm 9$ & $130 \pm 205$ & $282 \pm 442$ \\
5 March 2015 & $4.3 \pm 2.3$ & $104 \pm 82$ & $12.6 \pm 3.7$ & $41 \pm 24$ & $235 \pm 313$ & $483 \pm 651$ \\
\hline \multicolumn{7}{c}{ Daytime } \\
\hline 3 March /2015 & $0.9 \pm 0.7$ & $260 \pm 52$ & $15.4 \pm 3.4$ & $86 \pm 13$ & $358 \pm 304$ & $755 \pm 642$ \\
4 March 2015 & $1.9 \pm 1.9$ & $167 \pm 85$ & $14.8 \pm 2.4$ & $89 \pm 9$ & $259 \pm 224$ & $561 \pm 482$ \\
5 March 2015 & $5.0 \pm 2.5$ & $111 \pm 73$ & $15.2 \pm 2.9$ & $21 \pm 8$ & $462 \pm 297$ & $951 \pm 624$ \\
\hline \multicolumn{7}{c}{ Night } \\
\hline 3-4 March 2015 & $0.3 \pm 0.2$ & $146 \pm 123$ & $12.5 \pm 0.5$ & $100 \pm 1$ & $0.0 \pm 0.0$ & $0 \pm 0$ \\
4-5 March 2015 & $0.3 \pm 0.2$ & $146 \pm 123$ & $12.1 \pm 1.2$ & $77 \pm 12$ & $0.0 \pm 0.0$ & $0 \pm 0$ \\
\hline
\end{tabular}

a Direction perpendicular to the roof vents is $208^{\circ}$ for a wind from southwest (SW).

\section{Results and Discussion}

\subsection{Radiation Levels above the Crop}

The solar and PAR radiation measured at $2 \mathrm{~m}$ in height were similar in both areas of measurement (above the low tunnels and above the unprotected plants). Thus, the little differences observed in radiation should be caused by the shading of the greenhouse structure components (vents, wire nets, dirt on the cover, etc.). The presence of the low tunnel could be expected to significantly affect net radiation levels measured at $2 \mathrm{~m}$ in height above the crop, but no such significant differences have been observed between the two areas of the test, being slightly lower in the area without the low tunnel (Table 2).

Table 2. Radiation levels inside the greenhouse [average value \pm standard deviation]. $R_{i}$, inside solar radiation $\left[\mathrm{W} \mathrm{m}{ }^{-2}\right] ; R_{i-P A R}$, inside PAR radiation $\left[\mu \mathrm{mol} \mathrm{m}{ }^{-2} \mathrm{~s}^{-2}\right] ; R_{i-N}$, inside net radiation $\left[\mathrm{W} \mathrm{m}^{-2}\right]$. Subscripts: $w$, with low tunnel; $n w$, without low tunnel.

\begin{tabular}{ccccccc}
\hline Date & $\boldsymbol{R}_{\boldsymbol{i , w} \boldsymbol{w}}$ & $\boldsymbol{R}_{\boldsymbol{i}, n \boldsymbol{w}}$ & $\boldsymbol{R}_{\boldsymbol{i - P A R , w}}$ & $\boldsymbol{R}_{\boldsymbol{i - P A R , n w}}$ & $\boldsymbol{R}_{\boldsymbol{i - N , \boldsymbol { w }}}$ & $\boldsymbol{R}_{\boldsymbol{i - N , n w}}$ \\
\hline \multicolumn{7}{c}{ Daily } \\
\hline 3 March 2015 & $132 \pm 203$ & $120 \pm 184$ & $266 \pm 407$ & $250 \pm 381$ & $55 \pm 126$ & $52 \pm 124$ \\
4 March 2015 & $98 \pm 151$ & $93 \pm 141$ & $202 \pm 309$ & $193 \pm 293$ & $33 \pm 96$ & $30 \pm 93$ \\
5 March 2015 & $166 \pm 229$ & $146 \pm 205$ & $323 \pm 444^{*}$ & $301 \pm 414^{*}$ & $61 \pm 141$ & malfunction \\
\hline \multicolumn{7}{c}{ Daytime } \\
\hline 3 March 2015 & $272 \pm 217$ & $248 \pm 195$ & $549 \pm 433^{*}$ & $518 \pm 403^{*}$ & $141 \pm 136$ & $136 \pm 134$ \\
4 March 2015 & $201 \pm 162$ & $191 \pm 150$ & $415 \pm 330$ & $397 \pm 310$ & $98 \pm 103$ & $92 \pm 100$ \\
5 March 2015 & $335 \pm 222$ & $294 \pm 202$ & $652 \pm 428^{*}$ & $607 \pm 400^{*}$ & $163 \pm 139$ & malfunction
\end{tabular}

* Denote that there were statistical differences at the $99.0 \%$ confidence level (Fisher's least significant difference, LSD) between the values of radiation with low tunnels and without low tunnels.

\subsection{Air and Crop Temperature}

The air temperature at $1 \mathrm{~m}$ and $2 \mathrm{~m}$ of height was very similar in both areas analyzed, above the low tunnel and above unprotected plants (Figure 3 and Table 3). 

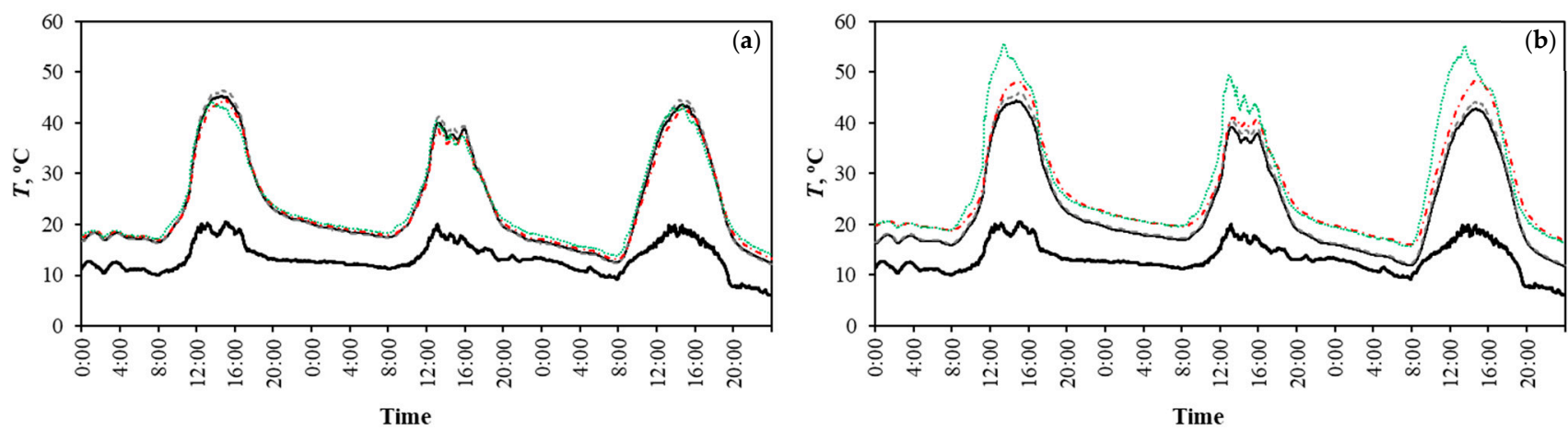

Figure 3. Temperature in the zone without low tunnel (a) and in the zone with low tunnel (b) measured from the

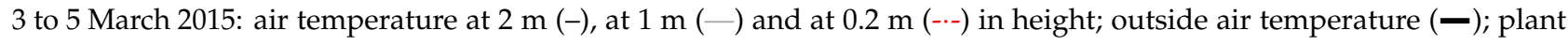
leaves temperature $(\cdots)$.

Table 3. Temperatures inside the greenhouse [average value \pm standard deviation]. $T_{i}$, air temperature [ ${ }^{\circ} \mathrm{C}$; $T_{c}$, crop temperature [ $\left.{ }^{\circ} \mathrm{C}\right]$. Subscripts: $w$, with low tunnel; $n w$, without low tunnel. Heights of air temperature measurements: two meters [2 m]; one meter [1 m] and zero point two meters [0.2]; crop temperature [crop].

\begin{tabular}{|c|c|c|c|c|c|c|c|c|}
\hline \multirow{2}{*}{ Date } & \multicolumn{2}{|c|}{$[2 \mathrm{~m}]$} & \multicolumn{2}{|c|}{ [1 m] } & \multicolumn{2}{|c|}{$[0.2 \mathrm{~m}]$} & \multicolumn{2}{|c|}{ [Crop] } \\
\hline & $T_{i, w}$ & $T_{i, n w}$ & $T_{i, w}$ & $T_{i, n w}$ & $T_{i, w}$ & $T_{i, n w}$ & $T_{c, w}$ & $T_{c, n w}$ \\
\hline \multicolumn{9}{|c|}{ Daily } \\
\hline 3 March 2015 & $24.9 \pm 9.8$ & $25.5 \pm 9.9$ & $25.5 \pm 10.2$ & $25.8 \pm 10.4$ & $27.8 \pm 9.9^{*}$ & $25.5 \pm 9.3 *$ & $29.3 \pm 12.0 *$ & $25.7 \pm 9.1 *$ \\
\hline 4 March 2015 & $23.0 \pm 7.5$ & $23.6 \pm 7.6$ & $23.5 \pm 7.9$ & $23.8 \pm 8.1$ & $25.9 \pm 7.4^{*}$ & $23.6 \pm 7.0^{*}$ & $27.0 \pm 9.2 *$ & $24.2 \pm 7.0 *$ \\
\hline 5 March 2015 & $22.3 \pm 10.9$ & $22.9 \pm 10.9$ & $22.9 \pm 11.3$ & $23.1 \pm 11.4$ & $26.8 \pm 11.3 *$ & $22.9 \pm 10.2 *$ & $28.4 \pm 13.6^{*}$ & $23.8 \pm 10.2$ * \\
\hline \multicolumn{9}{|c|}{ Daytime } \\
\hline 3 March 2015 & $31.5 \pm 10.3$ & $32.3 \pm 10.5$ & $32.5 \pm 10.8$ & $32.9 \pm 11.0$ & $34.4 \pm 10.7^{*}$ & $31.8 \pm 9.9^{*}$ & $37.7 \pm 12.5 *$ & $32 \pm 9.4 *$ \\
\hline 4 March 2015 & $28.3 \pm 7.7$ & $29.0 \pm 7.8$ & $29.2 \pm 8.1$ & $29.5 \pm 8.3$ & $31.0 \pm 7.8 *$ & $28.5 \pm 7.3$ * & $33.5 \pm 9.5 *$ & $29.3 \pm 7.1$ * \\
\hline 5 March 2015 & $30.5 \pm 10.2$ & $31.0 \pm 10.2$ & $31.4 \pm 10.5$ & $31.7 \pm 10.6$ & $35.2 \pm 10.7^{*}$ & $30.5 \pm 9.8^{*}$ & $38.9 \pm 12.4^{*}$ & $31.4 \pm 9.5^{*}$ \\
\hline \multicolumn{9}{|c|}{ Night } \\
\hline 3-4 March 2015 & $19.2 \pm 1.7^{*}$ & $19.9 \pm 1.7^{*}$ & $19.6 \pm 1.7$ & $19.7 \pm 1.7$ & $22.2 \pm 2.0^{*}$ & $20.3 \pm 1.7^{*}$ & $22.0 \pm 1.7^{*}$ & $20.6 \pm 1.7^{*}$ \\
\hline 4-5 March 2015 & $15.5 \pm 1.9 *$ & $16.1 \pm 1.9^{*}$ & $15.8 \pm 1.9$ & $15.9 \pm 2.0$ & $19.3 \pm 2.1^{*}$ & $16.6 \pm 1.9^{*}$ & $19.0 \pm 1.9 *$ & $17.3 \pm 2.0 *$ \\
\hline
\end{tabular}

* Denote that there were statistical differences at the $99.0 \%$ confidence level (Fisher's least significant difference, LSD) between the values of temperature with low tunnels and without low tunnels.

The air temperature ( 1 and $2 \mathrm{~m}$ height) was slightly lower above the low tunnel crop line in comparison with the crop line without the low tunnel (average daily difference of $-0.6 \pm 0.2^{\circ} \mathrm{C}$ ). In the area protected with the low tunnels, the energy lost by infrared radiation is reduced as a consequence of the reflection produced by the plastic cover of the tunnel. The low tunnel also reduced the heat exchanged by convection between the soil surface and the air around the plants (at $0.2 \mathrm{~m}$ ). As consequence, the low tunnel reduces the heat convection to the air at 1 and $2 \mathrm{~m}$.

Inside the low tunnel, the air temperature (area occupied by the crop) was significantly higher than in the area without the low tunnel (average daily difference of $2.8 \pm 1.2{ }^{\circ} \mathrm{C}$ ), with maximum differences of $4.0,3.7$ and $5.9^{\circ} \mathrm{C}$ on days 1,2 , and 3 of the test, respectively. Loy and Wells [22], comparing bare soil with clear polyethylene row cover in an open field, observing that the average temperature of daytime was $4.0^{\circ} \mathrm{C}$ higher using the row cover. During the night, air temperature increased only $0.5^{\circ} \mathrm{C}$ with the row cover. The value of $4.0^{\circ} \mathrm{C}$ of air temperature difference is well above the value of $2.8^{\circ} \mathrm{C}$ observed in our case. Perhaps, because we worked inside a greenhouse, reducing the effect of the low tunnels observed by Loy and Wells [22] working in an open field.

In our case, the air temperature inside the low tunnel was above $40{ }^{\circ} \mathrm{C}$ in the central hours of days 1 and 3 . Using low tunnels of $61 \mathrm{~cm}$ base and $38 \mathrm{~cm}$ of height and with different plastic materials (clear polyethylene, white polyethylene and spun-bonded polypropylene), Gerber et al. [6] observed the highest 1-day temperature $\left(55^{\circ} \mathrm{C}\right)$ under 
clear polyethylene, being $3-5{ }^{\circ} \mathrm{C}$ lower with spun-bonded polypropylene and $8{ }^{\circ} \mathrm{C}$ lower with white polyethylene, and $24^{\circ} \mathrm{C}$ lower without the low tunnel. Libik and Siwek [29], in a low tunnel $0.5 \mathrm{~m}$ of height with a watermelon crop, observed air temperatures above $35^{\circ} \mathrm{C}$ in spring. Optimal temperatures for the vegetative development of the watermelon plant range between 23 and $28^{\circ} \mathrm{C}$ [30]. With this protection technique applied in the early stages of plant growth, the development of the crop can be enhanced approaching these optimal temperatures in temperate climate conditions.

The major effect of this crop protection system was observed in the temperature of the plants, achieving an average increase of $3.8 \pm 3.2^{\circ} \mathrm{C}$ (during the three test days), in comparison with the crop without the low tunnel. The temperature difference reached its maximum value at noon on the third day of measurements $\left(13.0^{\circ} \mathrm{C}\right.$ difference). During the daytime period, the increase in crop temperature was $5.7 \pm 3.4^{\circ} \mathrm{C}, 4.2 \pm 2.5^{\circ} \mathrm{C}$, and $7.4 \pm 3.7^{\circ} \mathrm{C}$ for test days 1,2 , and 3, respectively. During the first night, the average temperature of the crop protected with the low tunnel increased by $1.4 \pm 0.1^{\circ} \mathrm{C}$ in comparison to the crop without the low tunnel $\left(1.7 \pm 0.1^{\circ} \mathrm{C}\right.$ during the second night).

\subsection{Absolute Air Humidity}

In the same way as for air temperature, the absolute humidity of the air was very similar (at $1 \mathrm{~m}$ and $2 \mathrm{~m}$ in height) in both zones, with and without low tunnels (Figure 4 and Table 4). Inside the low tunnel, a microclimate was generated in which the water content of the air rises significantly, as a consequence of the reduction in air convection and of the mixing with the bulk air inside the greenhouse. The average daily value of the absolute humidity of the air surrounding the crop (for the three days of the test) was $0.0131 \pm 0.0048 \mathrm{~g} / \mathrm{g}$ (without the low tunnel) and $0.0201 \pm 0.0098 \mathrm{~g} / \mathrm{g}$ (with the low tunnel); with mean daytime values of absolute air humidity, without the low tunnel of $0.0185 \pm 0.0057 \mathrm{~g} / \mathrm{g}$ (day 1), $0.0165 \pm 0.0041 \mathrm{~g} / \mathrm{g}$ (day 2), and $0.0131 \pm 0.0037 \mathrm{~g} / \mathrm{g}$ (day 3) and with the low tunnel of $0.0291 \pm 0.0121 \mathrm{~g} / \mathrm{g}$ (day 1), $0.0235 \pm 0.0073 \mathrm{~g} / \mathrm{g}$ (day 2), and $0.0272 \pm 0.0131 \mathrm{~g} / \mathrm{g}$ (day 3). The maximum values observed were $0.0265 \mathrm{~g} / \mathrm{g}$ without the low tunnel and $0.0477 \mathrm{~g} / \mathrm{g}$ with a low tunnel (during day 1). On average, for the three days of the test, the absolute humidity of the air inside the low tunnel was $50 \%$ greater than around the unprotected plants (without the low tunnel), increasing by $80 \%$ at the noon. The low tunnel system favors the crops such as watermelon and melon, which need extreme temperatures and high air humidity during the early stages of their development.

In the area occupied by the unprotected plants the maximum relative humidity observed was $86 \%$ (early in the morning), while inside the low tunnels, saturation $(\mathrm{RH}=100 \%)$ was reached in the early hours of the three mornings of measurements (from 9:00 to 10:00). During the night, air relative humidity remained above $90 \%$ inside the low tunnel and about $80 \%$ around unprotected plants (without the low tunnel).
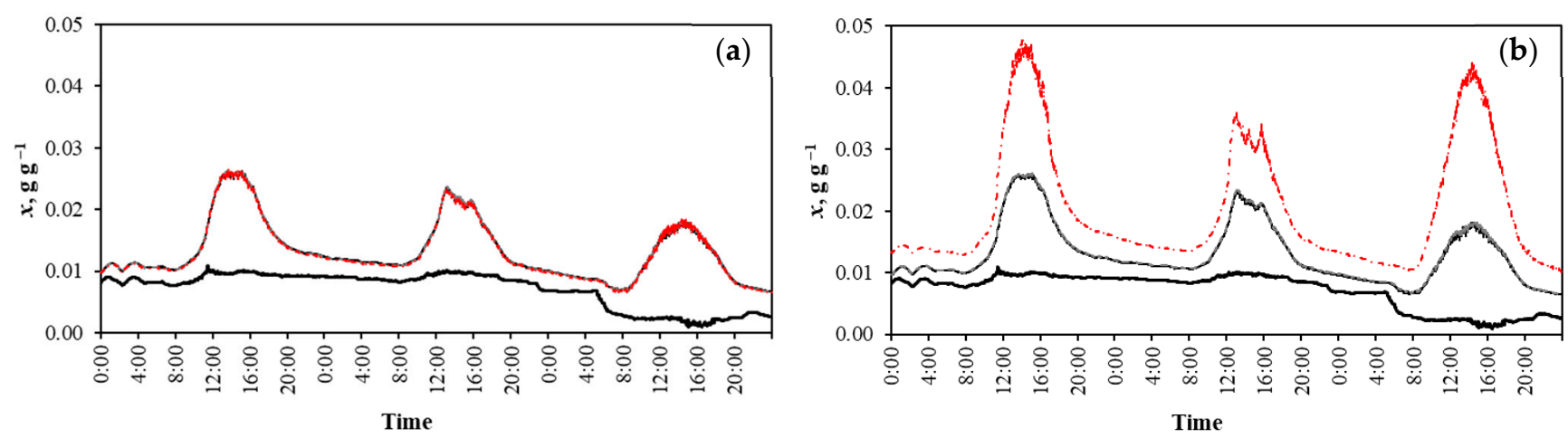

Figure 4. Humidity values in the zone without low tunnel (a) and in the zone with low tunnel (b) measured from the 3 to 5 March 2015: at $2 \mathrm{~m} \mathrm{(-),} 1 \mathrm{~m}(-)$ and $0.2 \mathrm{~m}(-\cdot-)$ in height; outside (-). 
Table 4. Absolute air humidity inside the greenhouse, $x_{i}\left[\mathrm{~g} \mathrm{~g}^{-1}\right.$ ] [average value \pm standard deviation]. Subscripts: $w$, with low tunnel; $n w$, without low tunnel. Heights of air temperature measurements: two meters [2 m]; one meter [1 m] and zero point two meters [0.2].

\begin{tabular}{|c|c|c|c|c|c|c|}
\hline \multirow{2}{*}{ Date } & \multicolumn{2}{|c|}{ [2 m] } & \multicolumn{2}{|c|}{ [1 m] } & \multicolumn{2}{|c|}{$[0.2 \mathrm{~m}]$} \\
\hline & $x_{i, w}$ & $x_{i, n w}$ & $x_{i, w}$ & $x_{i, n w}$ & $x_{i, w}$ & $x_{i, n w}$ \\
\hline \multicolumn{7}{|c|}{ Daily } \\
\hline 3 March 2015 & $0.0148 \pm 0.0054$ & $0.0151 \pm 0.0054$ & $0.0149 \pm 0.0054$ & $0.0151 \pm 0.0054$ & $0.0219 \pm 0.0110 *$ & $0.0149 \pm 0.0054$ * \\
\hline 4 March 2015 & $0.0136 \pm 0.0040$ & $0.0139 \pm 0.0040$ & $0.0137 \pm 0.0040$ & $0.0139 \pm 0.0040$ & $0.0189 \pm 0.0068 *$ & $0.0137 \pm 0.0039 *$ \\
\hline 5 March 2015 & $0.0104 \pm 0.0036$ & $0.0107 \pm 0.0035$ & $0.0106 \pm 0.0036$ & $0.0107 \pm 0.0036$ & $0.0195 \pm 0.0108^{*}$ & $0.0106 \pm 0.0036$ * \\
\hline \multicolumn{7}{|c|}{ Daytime } \\
\hline 3 March 2015 & $0.0184 \pm 0.0058$ & $0.0187 \pm 0.0057$ & $0.0186 \pm 0.0058$ & $0.0187 \pm 0.0058$ & $0.0291 \pm 0.0121 *$ & $0.0185 \pm 0.0057 *$ \\
\hline 4 March 2015 & $0.0164 \pm 0.0042$ & $0.0167 \pm 0.0041$ & $0.0166 \pm 0.0042$ & $0.0168 \pm 0.0042$ & $0.0235 \pm 0.0073$ * & $0.0165 \pm 0.0041$ * \\
\hline 5 March 2015 & $0.0129 \pm 0.0037$ & $0.0131 \pm 0.0036$ & $0.0130 \pm 0.0037$ & $0.0131 \pm 0.0036$ & $0.0272 \pm 0.0108 *$ & $0.0131 \pm 0.0037$ * \\
\hline \multicolumn{7}{|c|}{ Night } \\
\hline 3-4 March 2015 & $0.0118 \pm 0.0009 *$ & $0.0122 \pm 0.0009 *$ & $0.0120 \pm 0.0009 *$ & $0.0122 \pm 0.0009 *$ & $0.0155 \pm 0.0016^{*}$ & $0.0120 \pm 0.0009$ * \\
\hline 4-5 March 2015 & $0.0092 \pm 0.0012 *$ & $0.0096 \pm 0.0012 *$ & $0.0094 \pm 0.0011$ & $0.0095 \pm 0.0012$ & $0.0129 \pm 0.0015 *$ & $0.0094 \pm 0.0012$ * \\
\hline
\end{tabular}

* Denote that there were statistical differences at the $99.0 \%$ confidence level (Fisher's least significant difference, LSD) between the values of temperature with low tunnels and without low tunnels.

\subsection{Water Content in the Soil}

The use of the low tunnel reduced water evaporation from the soil surface, observing a noticeable increase $(60 \%)$ in water content in the soil under the protection (Figure 5). The average daily value of the soil water content for the three days analyzed was $0.2617 \pm 0.0089 \mathrm{~g} / \mathrm{g}$ (water mass/soil mass) without the low tunnel and $0.4242 \pm 0.0125 \mathrm{~g} / \mathrm{g}$ with the low tunnel. For the maximum observed values (during day 1), the water content was $0.2790 \mathrm{~g} / \mathrm{g}$ without the low tunnel and $0.4500 \mathrm{~g} / \mathrm{g}$ with the low tunnel.

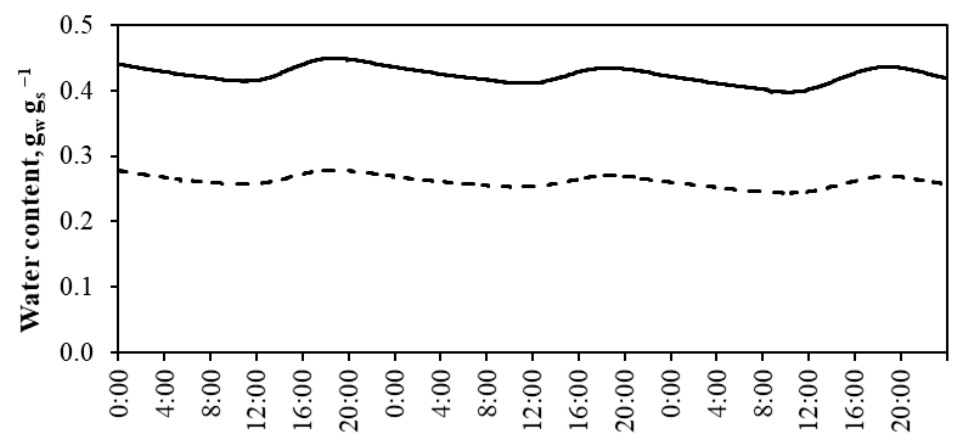

Time

Figure 5. Soil water content (water mass $g_{w} /$ soil mass $g_{s}$ ), measured at $0.20 \mathrm{~m}$ depth, from the 3 to 5 March 2015: without low tunnel (-); with low tunnel (-).

\subsection{Soil Temperature}

Figure 6 shows the time evolution of soil temperature at different depths, with the low tunnel and without the low tunnel. The soil temperature difference with the low tunnel and without the low tunnel decreases with depth (Figure 7). On the surface of the soil, the average temperature was $1.2 \pm 0.5^{\circ} \mathrm{C}$ higher with the low tunnel than without the low tunnel (during the 3 days of testing), while at $20 \mathrm{~cm}$ deep the value reached is $0.6 \pm 0.5^{\circ} \mathrm{C}$. A maximum temperature difference of $2.5^{\circ} \mathrm{C}$ on the soil surface was observed during the three days, and $1.3^{\circ} \mathrm{C}$ at $20 \mathrm{~cm}$ deep. During the daytime period, there was an average temperature increase on the soil surface of $1.6 \pm 0.5^{\circ} \mathrm{C}$ (day 1), $0.9 \pm 0.2{ }^{\circ} \mathrm{C}$ (day 2) and $1.8 \pm 0.5^{\circ} \mathrm{C}$ (day 3), and $20 \mathrm{~cm}$ deep of $0.8 \pm 0.3{ }^{\circ} \mathrm{C}$ (day 1), $0.5 \pm 0.2{ }^{\circ} \mathrm{C}$ (day 2) and $0.7 \pm 0.4^{\circ} \mathrm{C}$ (day 3). The effect at night was less evident, with increases in temperature on the soil surface from $0.7 \pm 0.2{ }^{\circ} \mathrm{C}$ (first night) to $1.0 \pm 0.3{ }^{\circ} \mathrm{C}$ (second night), and from $0.3 \pm 0.1{ }^{\circ} \mathrm{C}$ (second night) to $0.6 \pm 0.2^{\circ} \mathrm{C}$ (first night) at $20 \mathrm{~cm}$ deep. Libik and Siwek [29], 
in a low tunnel $0.5 \mathrm{~m}$ high with a watermelon crop in an open field, observed increases in soil temperature of $5.9^{\circ} \mathrm{C}$ (at 8:00) and $6.8^{\circ} \mathrm{C}$ (at 14:00) relative to the soil temperature in the area where the crop was unprotected (in spring). In the same way, Loy and Wells [22] observed an average soil temperature increase of $3.0^{\circ} \mathrm{C}$ (during the day) and $2.7^{\circ} \mathrm{C}$ (at night) with the row cover compared to the temperature of the bare soil for a muskmelon crop in an open field.

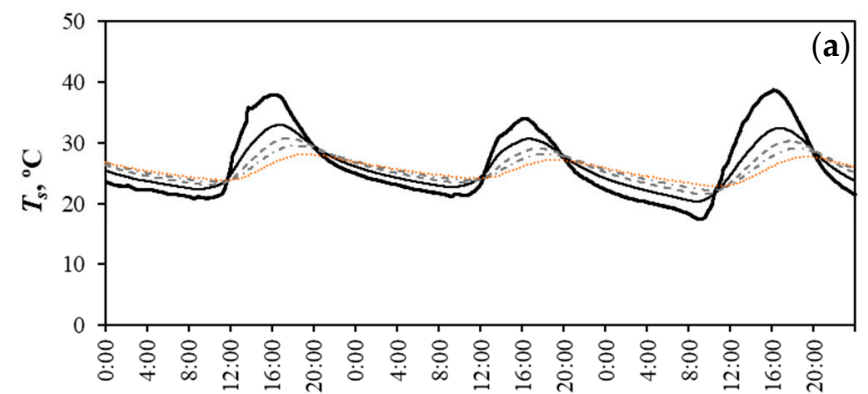

Time

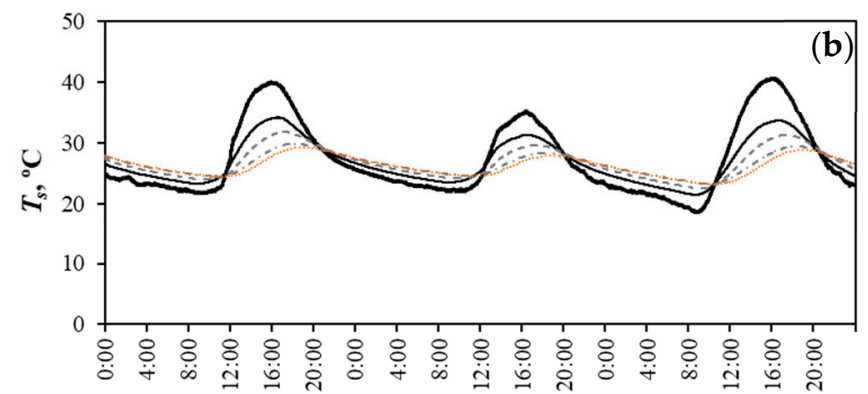

Time

Figure 6. Soil temperature without low tunnel (a) and with low tunnel (b) measured from the 3 to 5 March 2015: at $0 \mathrm{~m}$ (一), $0.05 \mathrm{~m}(-), 0.10 \mathrm{~m}(-), 0.15(-\cdot)$, and $0.20 \mathrm{~m}(\cdots)$ deep.

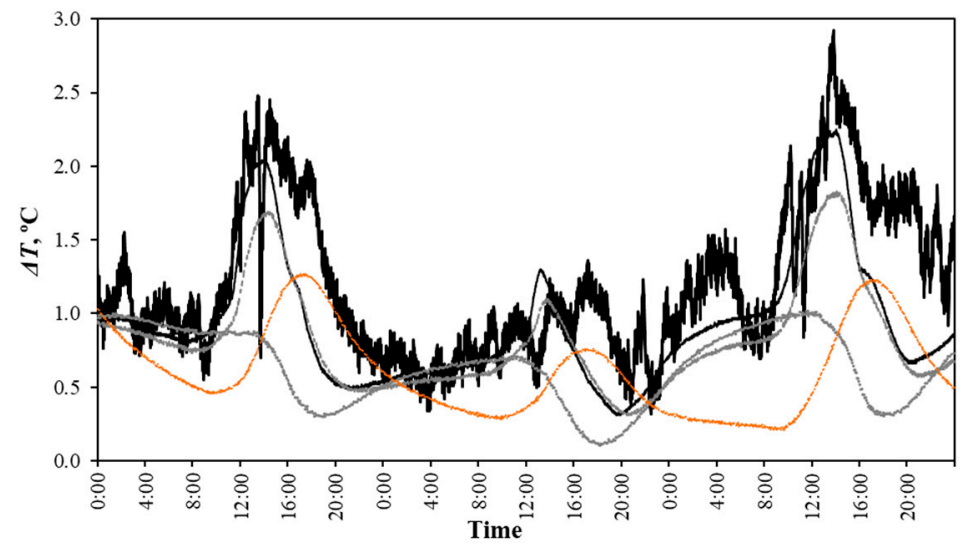

Figure 7. Difference in soil temperature with low tunnel and without low tunnel measured from the 3 to 5 March 2015: at $0 \mathrm{~m}(-), 0.05 \mathrm{~m}(-), 0.10 \mathrm{~m}(-), 0.15(\cdots)$, and $0.20 \mathrm{~m}(\cdots)$ depth.

In our case, the differences in soil temperature between the area with the low tunnel and without the low tunnel were lower than those obtained by Libik and Siwek [29] and Loy and Wells [22], possibly because they worked in an open field and we worked inside a greenhouse. Inside greenhouses, the effect of low tunnels observed for both air and soil temperatures, seems to be reduced in comparison with the results reported by other authors.

Figure 8 shows soil temperature profiles for different times of the day. From 0:00 $\mathrm{h}$ the soil gradually cooled, transferring heat by convection to the air and by radiation to the plants and the surrounding environment. Between 6:00 and 10:00 h the ground continued to transfer energy to the air, even if the sunrise had already occurred. From 10:00 to 14:00 there was a warming of the soil by solar radiation in the surface and by conduction in the rest of the depths analyzed, reducing the increase in temperature with depth. Soil temperature continues to rise during the afternoon (with maximum values at 18:00 h). At 22:00 $\mathrm{h}$, the bulk soil began to transfer heat by conduction to the upper layers. This heat is finally lost by conduction and radiation to the air, plants, and surrounding environment. A slow and progressive cooling of the soil is observed during the night period (Figure 9). The evolution of the temperature difference between the soil under the low tunnel and the unprotected zone (Figure 8) shows that below $15 \mathrm{~cm}$ depth the temperature difference 
remained below $1{ }^{\circ} \mathrm{C}$. Above $15 \mathrm{~cm}$ depth, the temperature difference increased, especially in the afternoon.
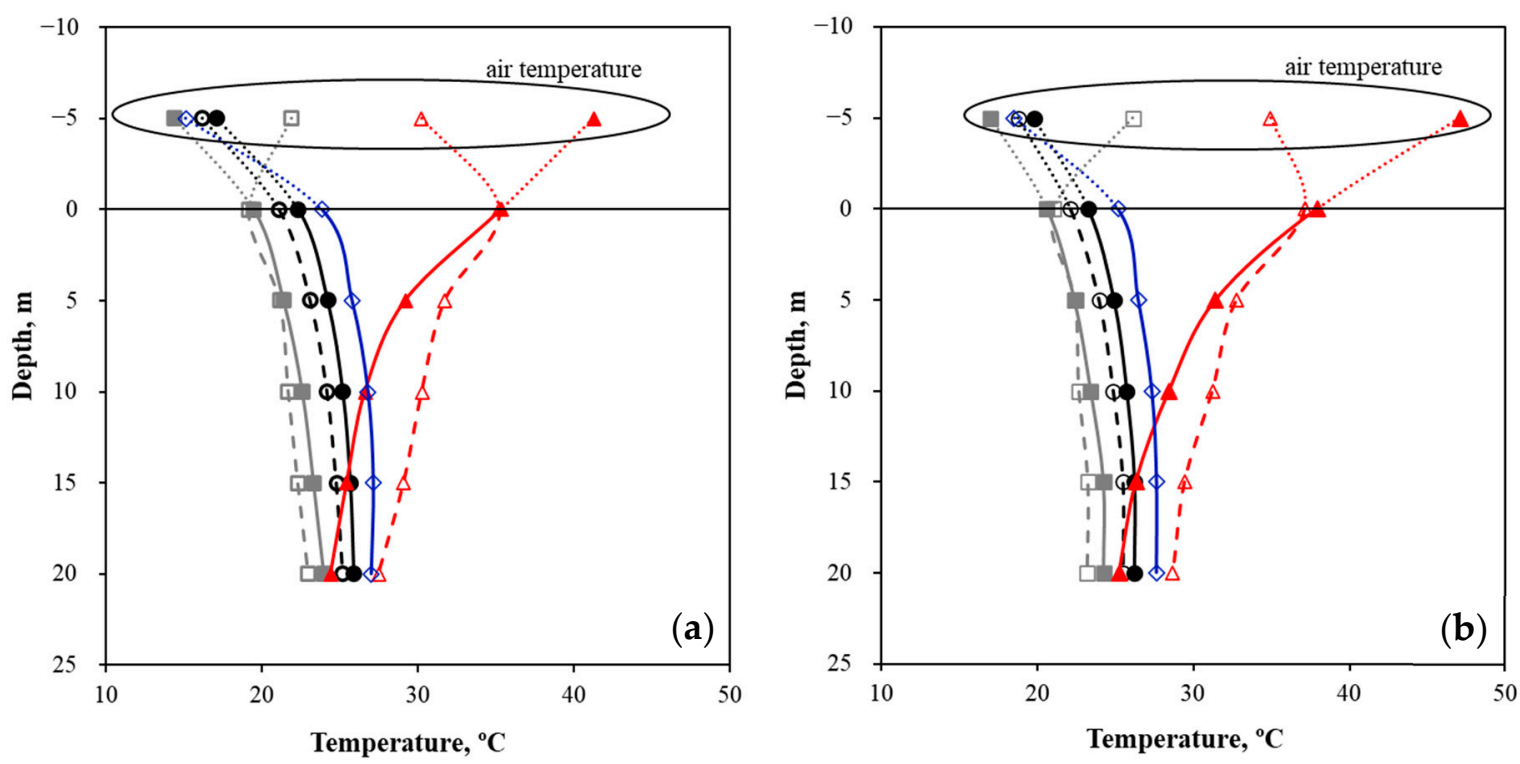

Figure 8. Soil temperature profile without low tunnel (a) and with tunnel (b) at different times on the third day of the test

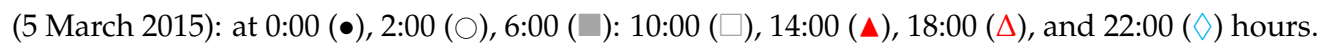

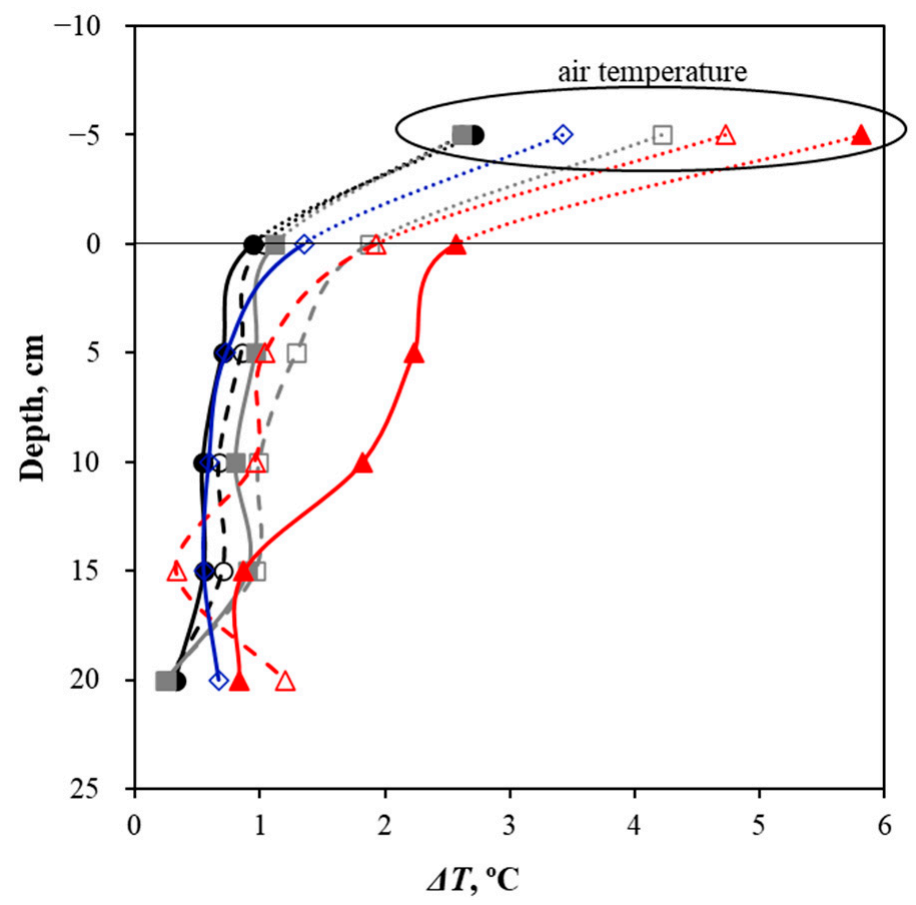

Figure 9. Difference in soil temperature with low tunnel and without low tunnel at different times on

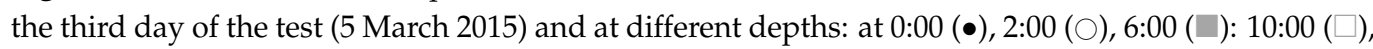
14:00 $(\Delta), 18: 00(\Delta)$, and 22:00 $(\diamond)$ hours. 


\section{Conclusions}

The use of the low tunnels increased average air temperature around plants from $24.0 \pm 9.0^{\circ} \mathrm{C}$ to $26.9 \pm 9.7^{\circ} \mathrm{C}$. A maximum difference in air temperature of about $5.9^{\circ} \mathrm{C}$ was observed at the noon. The average daily temperature of the crop was $28.2 \pm 11.8^{\circ} \mathrm{C}$ inside the row cover and $24.6 \pm 8.9^{\circ} \mathrm{C}$ without it. In the same way, the absolute humidity of air was clearly higher inside the low tunnel $(0.0201 \pm 0.0098 \mathrm{~g} / \mathrm{g})$ than around the plant rows without floating cover $(0.0131 \pm 0.0048 \mathrm{~g} / \mathrm{g})$. The soil temperature was also higher inside the low tunnel compared to the area without this second plastic cover. The effect of the tunnel decreases with depth, with average temperature differences of $1.2 \pm 0.5^{\circ} \mathrm{C}$ on the soil surface and $0.6 \pm 0.5^{\circ} \mathrm{C}$ at $20 \mathrm{~cm}$ depth.

Author Contributions: Conceptualization, F.D.M.-A., A.L.-M., A.P.-F. and D.L.V.-M.; methodology, F.D.M.-A., A.L.-M. and F.J.F.B.; data analysis, A.L.-M., F.D.M.-A. and M.d.l.Á.M.-T.; writing-original draft preparation, A.L.-M. and M.d.I.Á.M.-T.; review and editing, F.D.M.-A., D.L.V.-M., A.P.-F. and F.J.F.B.; project administration, D.L.V.-M.; funding acquisition, D.L.V.-M. All authors have read and agreed to the published version of the manuscript.

Funding: This research was funded by the MINISTERIO DE CIENCIA, INNOVACIÓN y UNIVERSIDADES of Spanish government, grant number PID2019-111293RB-I00, project "Improving profitability in greenhouses by increasing photosynthetic activity with passive climate control techniques (GREENPHOC)".

Institutional Review Board Statement: Not applicable.

Informed Consent Statement: Not applicable.

Acknowledgments: The authors wish to express their gratitude to the Research Centre CIAIMBITAL of the University of Almería (Spain) and the University of Almeria-ANECOOP Foundation for their collaboration and assistance during the development of this study.

Conflicts of Interest: The authors declare no conflict of interest.

\section{References}

1. Castilla, N.P. Invernaderos de Plástico: Tecnología y Manejo; Mundi-Prensa: Madrid, Spain, 2007; 462p. (In Spanish)

2. Sideman, B. Row Covers. In A Guide to the Manufacture, Performance, and Potential of Plastics in Agriculture, 1st ed.; Orzolek, M.D., Ed.; Elsevier: Amsterdam, The Netherlands, 2017; pp. 61-77.

3. Wells, O.S.; Loy, J.B. Rowcovers and High Tunnels Enhance Crop Production in the Northeastern United States. HortTechnology 1993, 3, 92-95. [CrossRef]

4. Wells, O.S.; Loy, J.B. Intensive vegetable production with row covers. HortScience 1985, 20, 822-826.

5. López-Aranda, J.M.; Soria, C.; Santos, B.M.; Miranda, L.; Dominguez, P.; Medina-Mínguez, J.J. Strawberry Production in Mild Climates of the World: A Review of Current Cultivar Use. Int. J. Fruit Sci. 2011, 11, 232-244. [CrossRef]

6. Gerber, J.M.; Mohd-Khir, I.; Splittstoesser, W.E. Row tunnel effects on growth, yield and fruit quality of bell pepper. Sci. Hortic. 1988, 36, 191-197. [CrossRef]

7. Valera, D.L.; Belmonte, L.J.; Molina-Aiz, F.D.; López, A. Greenhouse Agriculture in Almería: A Comprehensive Techno-Economic Analysis; Cajamar Caja Rural: Almería, Spain, 2016; 408p. Available online: http:/ /www.publicacionescajamar.es/series-tematicas/economia/ greenhouse-agriculture-in-almeria-a-comprehensive-techno-economic-analysis / (accessed on 21 June 2020).

8. Wittwer, S.H.; Castilla, N. Protected Cultivation of Horticultural Crops Worldwide. HortTechnology 1995, 5, 6-23. [CrossRef]

9. Tesi, R. Mezzi di Protezione per L'ortoflorofrutticoltura ed il Vivaismo Means of Protection for Horticulture and Nursery; Il Sole 24 Ore Edagricole: Milán, Italy, 1999; 244p. (In Italian)

10. Jenni, S.; Dubuc, J.-F.; Stewart, K.A. Plastic mulches and row covers for early and midseason crisphead lettuce produced on organic soils. Can. J. Plant Sci. 2003, 83, 921-929. [CrossRef]

11. Soltani, N.; Anderson, L.; Hamson, A.R. Growth Analysis of Watermelon Plants Grown with Mulches and Rowcovers. J. Am. Soc. Hortic. Sci. 1995, 120, 1001-1009. [CrossRef]

12. Gimenez, C.; Otto, R.F.; Castilla, N. Productivity of leaf and root vegetable crops under direct cover. Sci. Hortic. 2002, 94, 1-11. [CrossRef]

13. Wolfe, D.W.; Albright, L.D.; Wyland, J. Modeling row cover effects on microclimate and yield: I. Growth response of tomato and cucumber. J. Am. Soc. Hort. Sci. 1989, 114, 562-568.

14. Albright, L.D.; Wolfe, D.; Novak, S. Modeling row cover effects on microclimate and yield: II. Thermal model and simulations. J. Am. Soc. Hort. Sci. 1989, 114, 569-578.

15. Hernandez, J.; Soriano, T.; Morales, M.I.; Castilla, N. Row covers for quality improvement of Chinese cabbage (Brassica rapasubsp. Pekinensis). N. Z. J. Crop. Hortic. Sci. 2010, 32, 379-388. [CrossRef] 
16. Moreno, D.A.; Víllora, G.; Ruiz, J.M.; Romero, L. Growth conditions, elemental accumulation and induced physiological changes in Chinese cabbage. Chemosphere 2003, 52, 1031-1040. [CrossRef]

17. Arancibia, R.A.; Motsenbocker, C.E. Differential Watermelon Fruit Size Distribution in Response to Plastic Mulch and Spunbonded Polyester Rowcover. HortTechnology 2008, 18, 45-52. [CrossRef]

18. Sideman, R.G.; Brown, A.; Martin, C.A.; Hazzard, R.; Cavanagh, A. Temperature moderating effects of low tunnels over winter in cool climates. HortScience 2012, 47, S404-S405.

19. Castilla, N. Current Situation and Future Prospects of Protected Crops in the Mediterranean Region. Acta Hortic. 2002, 528, 135-147. [CrossRef]

20. Castilla, N.; Hernández, J. The plastic greenhouse industry in Spain. Chron. Hortic. 2005, 45, 15-20.

21. Ombódi, A.; Kemenczei, E.; Kassai, T.; Dimény, J. Effect of Different Low Tunnel Covers on Temperature Conditions and Development of Sweet Pepper. Acta Hortic. 2012, 936, 347-354. [CrossRef]

22. Loy, J.B.; Wells, O.S. Response of hybrid muskmelons to polyethylene row covers and black polyethylene mulch. Sci. Hortic. 1975, 3, 223-230. [CrossRef]

23. Jolliffe, P.A.; Gaye, M.-M. Dynamics of growth and yield component responses of bell peppers (Capsicum annuum L.) to row covers and population density. Sci. Hortic. 1995, 62, 153-164. [CrossRef]

24. Abak, K.; Güler, H.Y.; Sari, N.; Paksoy, M. Earliness and Yield of Physalis (P. ixocarpa Brot. and P. peruviana L.) In Greenhouse, Low Tunnel and Open Field. Acta Hortic. 1994, 366, 301-306. [CrossRef]

25. Ibarra, L.; Flores, J.; Díaz-Pérez, J.C. Growth and yield of muskmelon in response to plastic mulch and row covers. Sci. Hortic. 2001, 87, 139-145. [CrossRef]

26. Reyes-Rosas, A.; Molina-Aiz, F.D.; Valera, D.L.; López, A.; Khamkure, S. Development of a single energy balance model for prediction of temperatures inside a naturally ventilated greenhouse with polypropylene soil mulch. Comput. Electron. Agric. 2017, 142, 9-28. [CrossRef]

27. Moreno-Teruel, M.A.; Valera, D.; Molina-Aiz, F.D.; López-Martínez, A.; Peña, A.; Marín, P.; Reyes-Rosas, A. Effects of Cover Whitening Concentrations on the Microclimate and on the Development and Yield of Tomato (Lycopersicon esculentum Mill.) Inside Mediterranean Greenhouses. Agronomy 2021, 11, 860. [CrossRef]

28. López-Martínez, A.; Valera-Martínez, D.L.; Molina-Aiz, F.D.; Moreno-Teruel, M.D.L.; Peña-Fernández, A.; Espinoza-Ramos, K.E. Analysis of the Effect of Concentrations of Four Whitening Products in Cover Transmissivity of Mediterranean Greenhouses. Int. J. Environ. Res. Public Health 2019, 16, 958. [CrossRef] [PubMed]

29. Libik, A.; Siwek, P. Changes in Soil Temperature Affected by the Application of Plastic Covers in Field Production of Lettuce and Water Melon. Acta Hortic. 1994, 371, 269-274. [CrossRef]

30. Camacho, F. Técnicas de Producción en Cultivos Protegidos Production Techniques in Protected Crops; Caja Rural Intermediterránea (Cajamar): Almería, Spain, 2003; 776p. (In Spanish) 